\title{
Impact of Agricultural Technology Management Agency on Different Enterprises for the Enhancement of Production and Income to the Rural Economy of Nagaland
}

\author{
Imti Walling and Amod Sharma
}

Department of Agricultural Economics, Nagaland University, SASRD, Medziphema Campus, District: Dimapur - 797 106, Nagaland, India

Corresponding author: hodaec_sasrd@yahoo.co.in

\begin{abstract}
The present study was conducted in Mokokchung and Peren Districts of Nagaland. A sample of 160 respondents (out of the total, 80 were beneficiaries and 80 were non-beneficiaries of ATMA programme) were selected from both the districts from blocks and further from 8 villages based on proportionate simple random sampling method. The study shows an impact on crops, livestock as well as other selected enterprises on production and productivity of the beneficiaries of ATMA programme it may be concluded that it is due to the adoption of good varieties / species and management skill developed by them in the study area with especial reference to selected field crops, cereals, pulses, oil seeds, vegetables, animal husbandry, fishery and plantation crops by the adoption of production techniques and available technology adopted in the study area, further to access the impact on income level z-test being adopted, which justified the study to have an positive impact on the different selected enterprises.
\end{abstract}

Keywords: ATMA, impact, beneficiaries, non-beneficiaries, rural, economy.

The National Agricultural Technology Project (NATP) was initiated in India with World Bank support in year 1998 and phase wise ATMAs were established in pilot project districts. The successful experiment served as a basis to launch the scheme "Support to State Extension Programmes for Extension Reforms" in its first phase since 2005-2006 (Swanson, 2006). The scheme was scaled to 252 districts in the country during the $10^{\text {th }}$ plan (Godtland et. al., 2004). ATMA is a unique district level institution, which caters to activities in agriculture and allied departments adopting a Farming System Approach. ATMA, a registered society of key stakeholders involved in agricultural activities for sustainable agricultural development in the district is responsible for technology dissemination at the district level.

Consequently, in 2010 the scheme has been modified and strengthened with a strong manpower, infrastructure and activities such as provision of specialist and functionary and supporting staff, innovative support through a "Farmer Friend" at village level, revision in ATMA cafeteria, delegation of power to State Level Sanctioning Committee (SLSC) set up under Rashtriya Krishi Vikas Yojana (RKVY) etc. In Nagaland the ATMA programme was launched in 2005-2006 in three districts viz; Dimapur, Kohima and Mokokchung and it was continued as such in 2006-2007 also. ATMA programme was extended in all other eight districts of Nagaland in 2008-2009 i.e. Wokha, Peren, Kipheri, Zunheboto, Tuensang, Mon, Longleng and Phek, and covered the entire State of Nagaland (Walling and Sharma, 2015). Realizing the need of studying the progress and impact of the Agricultural Technology Management Agency, a study was conducted on "Impact of Agricultural Technology Management Agency on Rural Economy of Nagaland" with the following objective: 
1. To study the impact of ATMA beneficiaries over non-beneficiaries in productivity of crops and livestock in study area, and

2. To access the income impact of ATMA beneficiaries over non-beneficiaries in the study area in the study area.

\section{Database and Methodology}

The present study was conducted in the state of Nagaland by selecting two districts viz; Mokokchung and Peren both were selected purposively with the fact to provide all the relevant information, conveniently been obtained for conducting the present study. A three stage stratified random sampling technique was used for the selection of blocks, villages and respondent, in the first stage of sampling, two blocks from each district were randomly selected then in second stage from each block two villages were selected randomly, while in the third stage 8 villages were randomly selected. A total of 160 respondents were selected randomly altogether; out of which 80 were beneficiaries and 80 were non-beneficiaries of ATMA scheme.
The productivity, production, consumption and marketed surplus were studied with the help of tabular analysis. The significance of difference between the mean value of different economic parameters of beneficiaries and non-beneficiaries was tested by using Z-test.

\section{RESULTS AND DISCUSSION}

Table 2 reveals that the average production of principal field crops, livestock, fishery and plantation crops, which was measured in terms of $\mathrm{kg} / \mathrm{ha}$, $\mathrm{kgs}$ or 1/animal. The average productivity of field crops (cereals, pulses, oilseeds and vegetables), poultry, dairy, piggery, duckery, fishery and plantation crops, on beneficiary and non-beneficiary households, was observed as 2,122.75 and 2,031.25, 1,823.00 and 1,767.00, 1,867.00 and 1,813.00, 1567.00 and $1487.00,3234.00$ and $3058.00,2.45$ and $2.18,6.74$ and 6.23, 231.75 and 219.47, 2.347 and 2.143, 3,012.00 and $2945.00,11,342.00$ and $11,028.00 \mathrm{~kg} / \mathrm{ha}$ or $1 /$ animal, respectively. In all the measured parameters its shows beneficiaries better compared to nonbeneficiaries.

Table 1: Sample size of beneficiaries and non-beneficiaries respondents

\begin{tabular}{|c|c|c|c|c|c|c|c|}
\hline \multicolumn{3}{|c|}{ Groups } & Sample Size & Male & Female & Total & Average \\
\hline \multirow{8}{*}{ 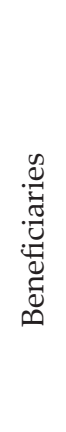 } & \multirow{4}{*}{  } & Small & $4(5.00)$ & $8(1.67)$ & $8(1.67)$ & $16(3.35)$ & 4.00 \\
\hline & & Medium & $14(17.50)$ & 44 (9.21) & 35 (7.32) & 79 (16.53) & 5.64 \\
\hline & & Large & $22(27.50)$ & 85 (17.78) & $51(10.67)$ & $136(28.45)$ & 6.18 \\
\hline & & Total & $40(50.00)$ & 137 (28.66) & 94 (19.67) & $231(48.33)$ & 5.78 \\
\hline & \multirow{4}{*}{ 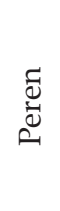 } & Small & $6(7.50)$ & $14(2.93)$ & $13(2.72)$ & 27 (5.65) & 4.50 \\
\hline & & Medium & $16(20.00)$ & 64 (13.39) & $40(8.37)$ & $104(21.76)$ & 6.50 \\
\hline & & Large & $18(22.50)$ & 70 (14.64) & $46(9.62)$ & $116(24.27)$ & 6.44 \\
\hline & & Total & $40(50.00)$ & $148(30.96)$ & 99 (20.71) & 247 (51.67) & 6.18 \\
\hline \multirow{10}{*}{ 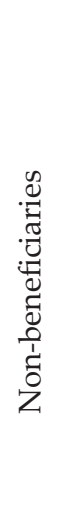 } & \multirow{5}{*}{ 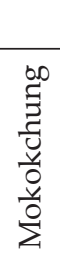 } & erall & $80(100)$ & $285(59.62)$ & $193(40.38)$ & $478(100)$ & 5.98 \\
\hline & & Small & $5(6.25)$ & $12(2.45)$ & $12(2.45)$ & $24(4.90)$ & 4.80 \\
\hline & & Medium & $11(13.75)$ & 35 (7.14) & $26(5.31)$ & $61(12.45)$ & 5.55 \\
\hline & & Large & $24(30.00)$ & 88 (17.96) & $59(12.04)$ & $147(30.00)$ & 6.13 \\
\hline & & Total & $40(50.00)$ & $135(27.55)$ & $97(19.80)$ & $232(47.35)$ & 5.80 \\
\hline & \multirow{5}{*}{ 莒 } & Small & $7(8.75)$ & 18 (3.67) & $17(3.47)$ & 35 (7.14) & 5.00 \\
\hline & & Medium & $14(17.50)$ & $57(11.63)$ & 35 (7.14) & 92 (18.78) & 6.57 \\
\hline & & Large & $19(23.75)$ & 78 (15.92) & $53(10.82)$ & $131(26.73)$ & 6.89 \\
\hline & & Total & $40(50.00)$ & $153(31.22)$ & 105 (21.43) & $258(52.65)$ & 6.45 \\
\hline & & rerall & $80(100)$ & $288(58.78)$ & $202(41.22)$ & $490(100)$ & 6.13 \\
\hline
\end{tabular}

The figure in the parenthesis indicates percentage in total. 
Table 2: Productivity of agriculture and livestock sector of beneficiaries and non-beneficiaries households

\begin{tabular}{|c|c|c|c|c|}
\hline Sl. No. & Enterprise & Beneficiary & Non-Beneficiary & Productivity \\
\hline 1. & Field crops $(\mathrm{kg} / \mathrm{ha})$ & 2122.75 & 2031.25 & $91.50(4.31)$ \\
\hline (a) & Cereals (kg/ha) & 1823.00 & 1767.00 & $56.00(3.07)$ \\
\hline (b) & Pulses (kg/ha) & 1867.00 & 1813.00 & $54.00(2.89)$ \\
\hline (c) & Oilseeds (kg/ha) & 1567.00 & 1487.00 & $80.00(5.11)$ \\
\hline (d) & Vegetables $(\mathrm{kg} / \mathrm{ha})$ & 3234.00 & 3058.00 & $176.00(5.44)$ \\
\hline 2. & Animal Husbandry & & & \\
\hline (a) & Poultry (kg/bird) & 2.45 & 2.18 & $0.27(11.02)$ \\
\hline (b) & Dairy (liter/animal) & 6.74 & 6.23 & $0.51(7.57)$ \\
\hline (c) & Piggery (kg/animal) & 231.75 & 219.47 & $12.28(5.30)$ \\
\hline (d) & Duckery (kg/animal) & 2.347 & 2.143 & $0.204(8.69)$ \\
\hline 3. & Fishery (kg/ha) & 3012.00 & 2945.00 & $67.00(2.22)$ \\
\hline 4. & Plantation crop (kg/ha) & 11342.00 & 11028.00 & $314.00(2.77)$ \\
\hline
\end{tabular}

Figures in parenthesis indicate percentage increase in productivity of crops on beneficiaries over non-beneficiaries households.

Table 3: Income from different sources of beneficiaries and non-beneficiaries household

\begin{tabular}{|c|c|c|c|c|c|c|c|}
\hline $\begin{array}{l}\text { Sl. } \\
\text { No. }\end{array}$ & Particulars & $\begin{array}{c}\text { Mean of } \\
\text { Beneficiaries }\end{array}$ & $\begin{array}{c}\text { Mean on Non- } \\
\text { Beneficiaries }\end{array}$ & Change & $\begin{array}{c}\text { SD of } \\
\text { Beneficiaries }\end{array}$ & $\begin{array}{l}\text { SD on Non- } \\
\text { Beneficiaries }\end{array}$ & $\mathrm{Z}$ values \\
\hline 1. & Field crops & 46696.25 & 41826.56 & 4869.69 (10.43) & 29686.76 & 29825.98 & $1102.58^{* * *}$ \\
\hline (a) & Cereals & 42843.75 & 38468.75 & $27912.59(65.15)$ & 28258.37 & 4375.00 & $996.55^{* * *}$ \\
\hline (b) & Pulses & 1351.50 & 1210.88 & $140.63(10.41)$ & 819.47 & 803.01 & $48.88^{* * * *}$ \\
\hline (c) & Oil seeds & 1559.38 & 1325.00 & 234.38 (15.03) & 846.85 & 629.45 & $81.02^{* * *}$ \\
\hline (d) & Vegetables & 713.50 & 636.00 & $77.50(10.86)$ & 441.53 & 406.39 & $29.67^{* * *}$ \\
\hline 2. & Animal husbandry & 68986.25 & 49031.48 & $19954.77(28.93)$ & 40181.47 & 24824.57 & $4386.54 *$ \\
\hline 3. & Fishery & 13500.00 & 5555.56 & 7944.44 (58.85) & 32747.60 & 21757.35 & $1780.88^{* *}$ \\
\hline 4. & Plantation crop & 14556.96 & 7453.70 & $7103.26(48.79)$ & 19985.89 & 13402.12 & 1671.70 *** \\
\hline
\end{tabular}

Figures in parenthesis indicate percentage to total; ${ }^{*}, *$ and $* * *$ Significant at 10,5 and 1 per cent of level of probability significance.

Table further reveals that the productivity enhancement was through replacement of different varieties on food grains and livestock species and also due to the ATMA programme training on production technology on different enterprises, productivity gain was the highest on poultry enterprise with 0.27 kilogram (11.02 per cent) weight gain bird $^{-1}$, followed by duckery enterprise with 0.204 kilogram (7.57 per cent) weight gain animal ${ }^{-1}$, while the dairy enterprise recorded as third venture with 0.51 litre (7.57 per cent) milk gain animal ${ }^{-1}$, the vegetable crops was the foremost among the field crops, vegetable is on leading with 176.00 kilogram (5.44 per cent) gain hectare ${ }^{-1}$, then piggery enterprise with 12.28 kilogram (5.30 per cent) weight gain animal $^{-1}$, the oilseeds crops gain with 80.00 kilogram (5.11 per cent) hectare ${ }^{-1}$, followed by cereals i. e; paddy crop with 56.00 kilogram (3.07 per cent) gain hectare $^{-1}$, as pulses was recorded minimum among the food grain crops with 54.00 kilogram (2.84 per cent) hectare ${ }^{-1}$, the plantation enterprise gain with 314.00 kilogram (2.77 per cent) hectare ${ }^{-1}$ and the least gain 67.00 kilogram (2.22 per cent) was recorded on fishery sector, which is mainly due to non-suitable species of fishes, also lack of training, good saplings, lack of skill and lack of proper management of fishery enterprise concept at village level.

Further data clearly indicates that there is impact on livestock enterprise in production and productivity by the adoption of good species of animals as well as food habit and social structure of the study areas. While the food grain varieties of long duration may be replace by introduction of short duration varieties as well as high-yielding varieties suit to the local areas, which is having highest production/ productivity per unit area. So, the present study 
clearly shows an impact of ATMA programme training by adoption of production techniques and available technology in the study area. The findings are in line with the findings of Malik (1990); Meena et al. (2012); Ngullie et al. (2014).

Thus, it can be concluded that production and productivity was having a positive impact of ATMA programme in the selected areas. The present research study findings are in conformity with the similar findings of Kumar and Sharma (1999); Barman and Kumar (2012); Meena et al. (2012); Sharma (2012) and Walling et al. (2017).

Table 3 reveals that the income gained from different sources / enterprises for both beneficiaries and nonbeneficiaries and to access the impact ' $Z$ ' test was adopted to justified the data as well as to do the test of significance. In field crops, cereals, pulses, oil seeds, vegetables, animal husbandry, fishery and plantation crops all showed significance at 1 per cent, which depicts that 99 per cent of the sources observed is homogenous. The present study findings are in conformity with the findings of Agarwal and Kumawat (1974); Bhalla and Hazell (2003); Kumar and Sharma (1999); Sharma et al. (2016) and Walling et al. (2017).

\section{CONCLUSION}

The main conclusion of the present study clearly indicates that there will be an positive impact on production and productivity on the different enterprises (especially crops, fishery, plantation and livestock enterprises) on the ATMA beneficiaries as compare to non-beneficiaries in term of quantity, as well as overall impact on production and productivity; which is an indication of positive impact on beneficiaries of ATMA scheme over non-beneficiaries varies from the minimum range of 2.22 per cent on fishery enterprise to the maximum impact of range to 11.02 per cent on poultry enterprises is justified, anyhow to justified statistically an ' $z$ ' test was adopted, which also showing an positive impact towards the increasing trend on all the selected different enterprises in the study area. Therefore, it may be concluded from the present study that there will be positive and statistically significant contribution at 1 per cent level on the ATMA beneficiaries as compare to the non-beneficiaries and having an overall impact on animal husbandry over the crop production in general too.

\section{REFERENCES}

Agarwal, N.L. and Kumawat, R.K. 1974. Potentialities of increasing farm income through credit in the district of Jaipur (Rajasthan). Agricultural Situation in India, 29(7): 483-489.

Anantharaman, M. and Ramanathan, S. 1990. Impact of training programme on tuber crops. Indian Journal of Extension Education, 26(1\&2): 103-106.

Barman, U. and Kumar, B. 2012. Knowledge level of extension personnel under ATMA regarding their facilitation skills. Agricultural Science Digest, 32(2): 145-148.

Bhalla, G.S. and Hazell, P. 2003. Rural employment and poverty: strategies to eliminate rural poverty within a generation. Economic and Political Weekly, 38(33): 34733484.

Bhange, S.B., Lande, S.B. and Sadaphal, S.S. 2005. Impact of National Watershed Development Programme. Asian Journal of Extension Education, 24: 62-64.

Godtland, E.M., Sadoulet, E., Janvry, A.D., Murgal, R. and Ortiz, O. 2004. The impact of Farmer Field Schools on knowledge and productivity. Economic Development and Cultural Change, 53(1): 63-92.

Hirevenkanagoudar, L.V., Chitambar, J.B. and Chaubey, B.K. 1984. Impact of National Demonstration on participant and non-participant farmers. Indian Journal of Extension Education, 20(1\&2): 76-78.

Kumar, R. and Sharma, A.K. 1999. Impact of dairy cooperatives on rural economy in Nalanda district. Journal of Dairying, Foods and Home Science, 18(2): 92-97.

Malik, W.H. 1990. Guides to farmers training. Journal of Rural Development and Administration, 22(4): 49-53.

Meena, G.L., Pant, D.C. and Burark, S.S. 2012. Impact assessment of NAIP project on livelihood and nutritional security of tribal dominated areas through integrated farming system and technology modules. Project Report. ATIC, MPUAT, Udaipur.

Ngullie, C., Das, S., Patra, N.K., Sahu, A.K. and Makar, A.K. 2014. Performance of Agricultural Technology Management Agency (ATMA) programme in the state of Nagaland, India. Journal of Interacademicia, 18(1): 117-127.

Sharma, Amod. 2012. Impact of Potato Cultivation Training on Village Extension Officers. Journal of Interacademicia. 16(4a): 1029-1035.

Sharma, Amod, Ezung, Portia Alex. and Sharma, Ratana. 2016. Impact Of Pineapple Cultivation Training On Village Extension Officer. Int. J. Multidisciplinary Approach and Studies, 3(1): 6-12. 
Swanson, B. 2006. The changing role of agricultural extension in a global economy. Journal of International Agricultural and Extension Education, 13(3): 5-17.

Walling, Imti. and Sharma, Amod. 2015. Impact of SGRY on beneficiaries and non-beneficiaries in Dimapur district of Nagaland. The Journal of Rural and Agricultural Research. 15(2): 90-94.
Walling, Imti., Sharma, Amod., Yadav, Mukesh. Kumar., Rajbhar, Arun, Kumar. and Kalai, Kankabati. 2017. Impact of Agricultural Technology Management Agency on Rural Economy of Nagaland, India. Plant Archiver, 17(2): 1511-1516. 
